\title{
KEWENANGAN HAKIM MENJATUHKAN PIDANA UANG PENGGANTI DALAM PERKARA KORUPSI YANG TIDAK DIDAKWAKAN PASAL 18 UU TIPIKOR
}

\author{
Juandra Juandra ${ }^{1}$, Mohd Din ${ }^{2}$, Darmawan Darmawan ${ }^{3}$ \\ ${ }^{1}$ Magister Ilmu Hukum Universitas Syiah Kuala, Banda Aceh \\ ${ }^{2,3}$ Fakultas Hukum Universitas Syiah Kuala, Banda Aceh \\ juandra94@gmail.com
}

\begin{abstract}
Abstrak
Tujuan penelitian ini untuk menemukan dan mengembangkan teori pemidanaan dan meningkatkan profesionalitas hakim khususnya hakim tipikor dalam mengadili perkara-perkara pidana yang hukumnya tidak jelas atau hukumnya tidak lengkap dengan meningkatkan kemampuan hakim melakukan penemuan hukum. Pasal 18 ayat 1 huruf $\mathrm{b}$ UU Tipikor berupa pidana uang pengganti merupakan karakteristik sanksi pidana dalam perkara korupsi yang merupakan pidana tambahan khusus yang bersifat sebagai hukum materiil yang belum diatur secara detiil penerapannya di dalam UU Tipikor dan Kitab Undang-Undang Hukum Acara Pidana (KUHAP). Masalah yang timbul dari kenyataan tersebut Seringkali penuntut umum dalam menagani perkara korupsi tidak mencantumkan pasal 18 UU Tipikor sehingga terjadi disparitas atau pertentangan putusan hakim berkaitan penjatuhan pidana uang pengganti. Metode penelitian yang digunakan adalah metode penelitian hukum normative. Hasil penelitian menunjukkan bahwa Pidana uang pengganti berupa sanksi yang sudah diatur di dalam rumusan UU Tipikor sebagai hukum materiil yang tidak menjadi unsur dari rumusan delik tidaklah menjadi keharusan bagi penuntut umum untuk mencantumkannya di dalam surat dakwaan, terjadi kesalahan pemahaman oleh hakim yang memandang bahwa penjatuhan pidana uang pengganti tidak dapat dijatuhkan apabila pasal 18 UU Tipikor tidak dicantumkan di dalam dakwaan, dakwaan hanya wajib merumuskan unsur perbuatan pidana (delik) apabila rumusan delik telah terpenuhi maka hkim dapat menjatuhkan sanksi pidana kepada terdakwa sesuai jenis pidana yang telah diatur dalam UU Tipikor.
\end{abstract}

Kata kunci: Kewenangan Hakim; Pidana Uang Pengganti; Tindak Pidana Korupsi

\section{THE JUDGES AUTHORITY TO SENTENCED THE SUBTITUE MONEY CRIMINAL IN THE UNCHARGED CORRUPTION CASES IN CLAUSE 18 CORRUPTION LAWS}

\begin{abstract}
The purpose of this research are to find out and develop the imprisonment theory and increase the judges profesionality, especially the corruption cases to ajudicate the unsure or uncomplete laws by increasing the judges ability doing laws invationIn the 18th clause, verse 1 and point $\mathrm{b}$ of corruption laws, subtitue money criminal are a characteristic of criminal penalty in the corruption case as a special additional law, which tend specifically unarranged practice material laws in corruption and criminal procedure code. The emerged problem of this case is the public prosecutors didn't include the clause when handle this case. The methods of this research is normative laws. The result indicate the subtitue money criminal as a penalty has been arranged in the formulated corruption cases as a material laws isn't one of the formulated offense for public prosecutors to include in the indictment. Theres a misunderstanding by the judges who assume that the subtitue money criminal can't be
\end{abstract}


p-ISSN : 2541-2345, e-ISSN : 2580-8842

sentenced if the clause 18 of corruption laws was not listed in the indictment. Those must formulated in offense. If the offense being fulfilled, the judges can sentence the criminal penalty to accused with the suitable criminal type in the corruption laws.

Keywords: Judges Authority; Subtitute Money; Corruption Case

\section{PENDAHULUAN}

\section{A. Latar Belakang Masalah}

Korupsi sebagai extra ordinary crime karena dampak yang ditimbulkan oleh tindak pidana ini merugikan secara tidak langsung kepada masyarakat luas. Korupsi seringkali dipandang oleh masyarakat sebagai perbuatan yang ditentang, dikutuk, dicaci dan dimaki, serta digambarkan sebagai perbuatan yang tidak bermoral dan berkaitan dengan keserakahan, dan ketamakan sekelompok masyarakat dengan menggunakan harta negara serta melawan hukum, penyalahgunaan jabatan serta perbuatan lain yang dipandang sebagai hambatan dan gangguan dalam membangun negara. ${ }^{1}$ Subjek tindak pidana yang dikenal dalam KUHP adalah orang perorangan. Dengan kata lain, hanya manusia yang dapat melakukan tindak pidana dan hanya manusia yang dapat dituntut serta dibebani pertanggungjawaban pidana. ${ }^{2}$

Kehadiran Undang-Undang Tindak Pidana Korupsi pada dasarnya disebabkan oleh keberadaan kodifikasi hukum pidana materiil (KUHP) maupun kodifikasi hukum pidana formil dalam KUHAP yang tidak mampu dalam memecahkan persoalan hukum yang terjadi di masyarakat. ${ }^{3}$ Saat ini UU Tipikor yang berlaku di Indonesia adalah Undang-Undang Nomor 31 Tahun 1999 Tentang Pemberantasan Tindak Pidana Korupsi Jo Undang-Undang Nomor 20 Tahun 2001 Tentang Perubahan Undang-Undang nomor 31 tahun 1999 tentang Perubahan Undang-Undang Nomor 31 Tahun 1999 Tentang Pemberantasan Tindak Pidana Korupsi (selanjutnya disebut UU Tipikor).

Permasalahan tentang korupsi di Indonesia masih menjadi pekerjaan utama dalam upaya pemberantasan korupsi. Telah ada beberapa pengaturan yang mengatur tentang tindak pidana korupsi. ${ }^{4}$ Terdapat 4 (empat) alasan memasukkan Undang-Undang Pemberantasan Tindak Pidana Korupsi ke dalam aturan hukum pidana khusus. ${ }^{5}$ Pertama, terkait dengan pengaturan

\footnotetext{
${ }^{1}$ Henny Juliani Abdul Fatah, Nyoman Serikat Putra Jaya, "Kajian Yuridis Penerapan Unsur Merugikan Keuangan Negara Dalam Penegakan Hukum Tindak Pidana Korupsi," Diponegoro Law Review 6, no. 31 (2017): 1-15.

2 Rizqi Purnama Puteri, Muhammad Junaidi, and Zaenal Arifin, "Reorientasi Sanksi Pidana Dalam Pertanggungjawaban Korporasi Di Indonesia," Jurnal Usm Law Review 3, no. 1 (2020): 98-111, https://doi.org/10.26623/julr.v3i1.2283.

${ }^{3}$ Mahrus Ali, Asas, Teori \& Praktek Hukum Pidana Korupsi (Yogyakarta: UII Press, 2013).

${ }^{4}$ Bahrudin Machmud, Muhammad Junaidi, and Amri Panahatan Sihotang, "Reposisi Kedudukan Justice Collaborator Dalam Upaya Pemberantasan Tindak Pidana Korupsi," USM Law Review 4, no. 1 (2021): 362-77, https://doi.org/http://dx.doi.org/10.26623/julr.v4i1.3368.

5 Ali, Asas, Teori \& Praktek Hukum Pidana Korupsi.
} 
tindak pidana. Undang-Undang Tindak Pidana Korupsi dengan tegas memandang bahwa pidana bagi tindak pidana percobaan, permufakatan jahat, dan pembantuan sama dengan delik selesai. Kedua, terkait dengan pertanggungjawaban pidana. Undang-Undang Tindak Pidana Korupsi tidak hanya menjadikan manusia sebagai subjek delik, tetapi juga korporasi. Ketiga, terkait dngan sanksi pidana. Undang-Undang Tindak Pidana Korupsi mengatur perumusan ancaman pidana secara kumulatif, dan kumulatif-alternatif, serta ancaman pidana minimum khusus. Keempat, terkait dengan hukum acara pidana. Undang-Undang Tindak Pidana Korupsi mengatur ketentuan beracara yang berbeda atau menyimpang dari ketentuuan beracara dalam KUHAP, seperti diakuinya sistem pembalikan beban pembuktian, perampasan aset, pembayaran uang pengganti dan peradilan in absentia.

Pidana uang pengganti secara tegas dinyatakan sebagai pidana tambahan bukan sebagai pidana pokok. Meskipun ketentuan Pasal 17 tersebut memberikan kepastian hukum terhadap penambahan pidana uang pengganti kepada koruptur namun disayangkan di dalam UU Tipikor tidak mengatur secara khusus hukum formilnya bagaimana tentang tata cara penerapan pasal 18 UU Tipikor, sehingga dalam penanganan perkara korupsi, masing-masing penegak hukum memiliki penafsiran berbeda-beda. Praktik penanganan perkara korupsi, jaksa penuntut umum tidak selalu mencantumkan Pasal 18 di dalam surat dakwaannya, ada kalanya penuntut umum menjerat seorang koruptor dengan surat dakwaan mencantumkan Pasal 18 UU Tipikor, namun tidak jarang pula tanpa menggunakan Pasal 18 UU Tipikor tersebut.

Praktiknya sering kali ditemukan putusan hakim yang bertentangan dengan fakta-fakta yang terungkap di persidangan. Contohnya putusanputusan hakim yang memeriksa, mengadili, dan memutus kasus tindak pidana korupsi yang merugikan keuangan negara. Masyarakat banyak mengeluhkan berbagai problem putusan hakim di Pengadilan Tindak Pidana Korupsi yang tidak sesuai dengan bukti-bukti yang muncul di persidangan. ${ }^{6}$

Selain dari kondisi di atas, masih sering ditemukan dalam penanganan perkara korupsi meskipun perbuatan terdakwa ditemukan indikasi kuat telah memenuhi unsur Pasal 2 dan 3 UU Tipikor serta belum mengembalikan kerugian negara selama proses penyidikan, namun surat dakwaan penuntut umum tetap tidak mencantumkan ketentuan Pasal 18 UU Tipikor, tetapi di dalam surat tuntutan pidana (requisitoir), penuntut umum tetap menuntut supaya terdakwa dijatuhi pidana uang pengganti.

${ }^{6}$ Ade Mahmud, "Problematika Asset Recovery Dalam Pengembalian Kerugian Negara Akibat Tindak Pidana Korupsi,” Jurnal Yudisial 11, no. 3 (2018): 347, https://doi.org/10.29123/jy.v11i3.262. 
Penelitian tentang kewenangan hakim dalam menjatuhkan pidana uang penggantu pada kasus tindak pidana korupsi telah diangkat oleh Mulyadi dkk (2016), penelitian tesebut fokus kepada dasar penjatuhan dan pertimbangan hakim dalam penjatuhahn hukuman badan sebagai pengganti pembayaran uang pengganti, selain itu penelitian tersbut juga meneliti tentang penerapan hukumnya bagaimana jika terpidana meninggal sebelum hukuman pengganti dilaksnakan. Penelitian ini lebih fokus mengkaji tentang apa yang menjadi dasar dan pertimbanagn hakim dalam menerapkan hukuman badan sebagai pengganti uang pengganti. ${ }^{7}$

Sedangkan penelitan Mahmud (2017) mengangkat permasalahan tentang dinamika pembayaran pidana uang pengganti akibat tindak pidana korupsi dalam upaya pemulihan asset dan strategi penegakan hukum pidana untuk mengatasi dinamika pidana uang pengganti. Hasil dari penelitian ini menunjukkan bahwa ada ruang bagi hakim dalam memberikan pidana penjara yang relatif lebih ringan daripada membayar uang pengganti. Perlunya strategi penegakan hukum pidana untuk mengatasi dinamika pidana uang pengganti adalah menerapkan konsep hukum progresif yaitu melalui sita jaminan sehingga akan menimbulkan efek jera bagi koruptor. ${ }^{8}$

Sedangkan penelitian Noviyanti dkk (2019) meneliti tentang penerapan "Perma Nomor 5 Tahun 2014 tentang Pidana Tambahan Uang Pengganti Dalam Tindak Pidana Korupsi" dalam usaha mengembalikan kerugian keuangan negara hasil dari tindak pidana korupsi dan penerapan pidana pembayaran uang pengganti dapat memberikan keadilan dan kepastian hukum bagi justisiabelen. Hasil dari penelitian ini adalah hakim dalam menerapkan ketentuan yang ada di Perma tentang uang pengganti belum merata. Hal tersebut dipengaruhi oleh pandangan dan pendapat hakim akan materi pidana tambahan pengganti yang tidak sama. ${ }^{9}$

Perbedaan penelitian ini dengan penelitian sebelumnya adalah penelitian ini fokus mengkaji kewenangan hakim dalam menjatuhkan pidana uang pengganti sesuai dengan Pasal 18 UU Tipikor yang tidak didakwakan, yang mana hal ini berbeda dengan penelitian Noviyanti dkk yang mengkaji penerapan pidana uang pengganti berdasarkan Perma No 5 Tahun 2014. Sedangkan penelitian Mulyadi dkk (2016) lebih fokus mengkaji apa yang

\footnotetext{
7 Hasim Purba Mahmud Mulyadi, M. Hamda, "Tinjauan Yuridis Terhadap Putusan Hakim Dalam Penjatuhan Hukuman Badan Sebagai Pengganti Dalam Pembayaran Uang Pengganti Dalam Perkara Tindak Pidana Korupsi," USU Law Journal 4, no. 2 (2016): 42-55.

8 Ade Mahmud, "Dinamika Pembayaran Uang Pengganti Dalam Tindak Pidana Korupsi," Jurnal Hukum Mimbar Justitia 3, no. 2 (2017): 137-56.

${ }^{9}$ Rahma Noviyanti, Elwi Danil, and Yoserwan Yoserwan, "Penerapan Perma Nomor 5 Tahun 2014 Tentang Pidana Tambahan Uang Pengganti Dalam Tindak Pidana Korupsi," Jurnal Wawasan Yuridika 3, no. 1 (2019): 1, https://doi.org/10.25072/jwy.v3i1.236.
} 
menjadi dasar dan pertimbangan hakim dalam menjatuhkan pidana penjara daripada pidana uang pengganti. Penelitian oleh Mahmud meneliti tentang dinamika yang ada dalam pengambilan keputusan hakim tentang pidana tambahan uang pengganti. Dalam penelitian ini masih ditemukan penerapan hukuman pidana penjara sebagai pengganti pidana uang pengganti yang relatif lebih ringan oleh hakim. Tujuan penelitian ini untuk menemukan dan mengembangkan teori pemidanaan dan meningkatkan profesionalitas hakim khususnya hakim Tipikor dalam mengadili perkara-perkara pidana yang hukumnya tidak jelas atau hukumnya tidak lengkap dengan meningkatkan kemampuan hakim melakukan penemuan hukum.

\section{B. Perumusan Masalah}

Rumusan masalah dalam penelitian ini adalah sebagai berikut:

1. Apakah hakim berwenang menjatuhkan pidana uang pengganti dalam perkara korupsi yang tidak didakwakan Pasal 18 UU Tipikor?

2. Bagaimana pelaksanaan putusan hakim tentang pidana uang pengganti dalam perkara yang tidak didakwakan Pasal 18 UU Tipikor?

\section{Metodologi Penelitian}

Menurut jenisnya, metode penelitian hukum dibedakan menjadi dua, yaitu penelitian hukum normatif dan penelitian hukum empiris. ${ }^{10}$ Metode penelitian hukum empiris disebut juga penelitian lapangan, yang dilakukan untuk mendapatkan data secara langsung dari masyarakat atau pihak-pihak yang berwenang melalui observasi, wawancara ataupun kuisioner. Metode penelitian hukum normatif disebut juga dengan istilah penelitian kepustakaan, karena dalam penelitian hukum normatif dilakukan dengan cara meneliti bahan-bahan pustaka atau data sekunder saja.

Penelitian ini adalah penelitian yuridis normatif, yang ditujukan untuk mengkaji kaidah/asas hukum yang berkaitan dengan masalah. Penelitian hukum normatif artinya "penelitian yang menitik beratkan terhadap data yang didapat dari aturan-aturan atau norma hukum positif dan menjadi bahan acuan utama dalam penelitian ini". Jenis penelitian ini adalah "deskriptif analitis, karena bertuuan untuk memberikan gambaran mengenai fakta-fakta yang relevan dengan permasalahan". Metode pendekatan yang digunakan dalam penelitian ini adalah "metode pendekatan yuridis normatif yang menitik beratkan pada penelitian data kepustakaan".

Untuk menganalisis data dan menarik kesimpulan dari hasil penelitian, dari ketiga bahan hukum, yaitu "bahan hukum primer, bahan hukum sekunder dan bahan hukum tertier, disajikan dalam bentuk kualitatif dengan menggunakan metode deskriptif”.

${ }^{10}$ Soerjono Soekanto dan Sri Mamudji, Penelitian Hukum Normatif (Suatu Tinjauan Singkat) (Jakarta: Raja Grafindo Persada, 2010). 
p-ISSN : 2541-2345, e-ISSN : 2580-8842

\section{HASIL DAN PEMBAHASAN}

\section{A. Kewenangan Hakim Dalam Penjatuhan Pidana Uang Pengganti}

Aspirasi masyarakat untuk memberantas korupsi semakin meningkat, karena korupsi telah menimbulkan kerugian yang sangat besar.Untuk itu upaya pencegahan dan pemberantasan korupsi perlu semakin ditingkatkan dan diintensifkan dengan tetap menjunjung tinggi hak asasi manusia dan kepentingan masyarakat. ${ }^{11}$

Undang-Undang tindak pidana korupsi telah dirumuskan sebagai tindak pidana formil, pengertian pegawai negeri telah diperluas, pelaku korupsi tidak didefenisikan hanya kepada orang perorang tetapi juga pada korporasi, sanksi yang dipergunakan adalah sanksi minimum sampai pidana mati, seperti yang tercantum dalam Pasal 2 dan Pasal 3 Undang-Undang Tahun 1999 Tentang Pemberantasan Tindak Pidana Korupsi dan telah pula dilengkapi dengan pengaturan mengenai kewenangan penyidik, penuntut umumnya hingga hakim yang memeriksa di sidang pengadilan. ${ }^{12}$

Diaturnya pidana uang pengganti dalam UU Tipikor tidak terlepas karena semakin maraknya perkara korupsi yang terjadi, pemerintah kesulitan untuk mewujudkan pembangunan nasional. besarnya dampak Tindak pidana korupsi, sehingga di dalam penjelasan umum UU Nomor 20 tahun 2001 tentang UU Tipikor kembali ditegaskan “... mengingat korupsi di Indonesia terjadi secara sistematik dan meluas sehingga tidak hanya merugikan keuangan negara, tetapi juga telah melanggar hak-hak sosial dan ekonomi masyarakat secara luas, maka pemberantasan korupsi perlu dilakukan dengan cara luar biasa. Dengan demikian pemberantasan korupsi harus dilakukan dengan cara yang khusus antara lain dengan penerapan sistem pembuktian terbalik yakni pembuktian yang dibebankan kepada terdakwa.

Tujuan pidana uang pengganti tidak lain adalah untuk memidana seberat mungkin para koruptor agar mereka jera dan untuk menakuti orang lain agar tidak melakukan korupsi. Tujuan lainnya adalah untuk mengembalikan uang negara yang hilang akibat korupsi. Pemikiran ini sejalan dengan defenisi tindak pidana korupsi, menurut undang-undang salah satu unsur tindak pidana korupsi (tipikor) adalah adanya tindakan yang "merugikan keuangan negara" dengan

11 Aryas Adi Suyanto, "Komisi Pemberantasan Korupsi Sebagai Lembaga Korupsi Di Indonesia," Jurnal USM Law Review 1, no. 1 (2018): 39-67, https://doi.org/http://dx.doi.org/10.26623/julr.v1i1.2231.

12 Dahlan Ali, "Eksekusi Uang Pengganti Terhadap Terpidana Dalam Tindak Pidana Korupsi Oleh Kejaksaan Tinggi Aceh," Kanun: Jurnal Ilmu Hukum 18, no. 2 (2016): 319-36, https://doi.org/10.24815/kanun.v18i2.5927. 
adanya unsur ini, maka setiap terjadi suatu korupsi pasti timbul kerugian pada keuangan negara. ${ }^{13}$

Ketentuan uang pengganti sebagai pidana tambahan diatur dalam "Undang-Undang Nomor 31 Tahun 1999 tentang Pemberantasan Tindak Pidana Korupsi", sebagaimana diubah dengan "Undang-Undang Nomor 20 Tahun 2001 tentang Perubahan atas Undang-Undang Nomor 31 tahun 1999 tentang Pemberantasan Tindak Pidana Korupsi (UUTPK)". Penerapan uang pengganti yang telah berlaku terbukti belum efektif mengupayakan pengembalian kerugian keuangan negara secara optimal karena pengaturan pengembalian kerugian keuangan negara melalui ketentuan uang pengganti dalam undang-undang tersebut belum memenuhi tujuan hukum. Menyadari kompleksnya permasalahan korupsi maka pemberantasannya harus dilakukan dengan cara yang tegas dengan melibatkan semua potensi yang ada dalam masyarakat khususnya pemerintah dan aparat penegak hukum. ${ }^{14}$

Peraturan perundang-undangan tidak memberikan aturan yang lengkap berkaitan surat dakwaan, namun secara sederhana dapatlah ditarik kesimpulan surat dakwaan merupakan suatu akta yang dibuat oleh penuntut umum yang berisi tentang tuduhan kepada seorang terdakwa telah melakukan suatu perbuatan pidana dengan menguraiakan tempat, waktu dan tempat perbuatan pidana yang diuraikan secara lengkap, sederhana dan cermat disertai menyebutkan perbuatan pidana (delik) yang dilanggarnya yang menjadi dasar bagi hakim menjatuhkan putusan kepada terdakwa".

Putusan pemidanaan diatur dalam Pasal 193, yang berarti terdakwa dijatuhi hukuman pidana sesuai dengan ancaman yang ditentukan dalam pasal tindak pidana yang didakwakan kepada terdakwa. Apabila menurut pendapat dan penilaian pengadilan terdakwa telah terbukti secara sah dan meyakinkan melakukan kesalahan tindak pidana yang didakwakan kepadanya sesuai dengan sistem pembuktian dan asas batas minimum pembuktian dan asas batas minimum pembuktian yang ditentukan dalam Pasal 183 KUHAP, kesalahan terdakwa telah cukup terbukti dengan sekurang-kurangnya dua alat bukti yang sah yang memberi keyakinan kepada hakim, terdakwalah pelaku tindak pidananya. ${ }^{15}$

\footnotetext{
13 Nastiti Rahajeng Putri, "Penjatuhan Pidana Uang Pengganti Sebagai Pidana Tambahan Dalam Perkara Tindak Pidana Korupsi," Jurnal Ilmiah Galuh Justisi 6, no. 1 (2018): 42, https://doi.org/10.25157/jigj.v6i1.1239.

14 Ali, "Eksekusi Uang Pengganti Terhadap Terpidana Dalam Tindak Pidana Korupsi Oleh Kejaksaan Tinggi Aceh."

15 Yonathan Sebastian Laowo, “Analisis Yuridis Putusan Bebas Dalam Tindak Pidana Korupsi," Education And Development 4, no. $1 \quad$ (2018): 90-91, http://journal.ipts.ac.id/index.php/ED/article/view/281/158.
} 
Penjatuhan putusan yang dilakukan hakim merupakan suatu proses yang kompleks dan sulit, seorang hakim harus meyakini apakah seorang terdakwa melakukan tindak pidana ataukah tidak, atau dalam perkara perdata, apakah ada sengketa hukum yang terjadi di antara pihak penggugat dan tergugat, dengan tetap berpedoman dengan pembuktian untuk menentukan kesalahan dan perbuatan yang dilakukan oleh seorang pelaku pidana, atau untuk menentukan adanya pelanggaran hukum yang dilakukan oleh salah satu pihak yang berperkara.

Putusan hakim dalam perkara pidana, dapat berupa putusan penjatuhan pidana, jika perbuatan pelaku tindak pidana terbukti secara sah dan meyakinkan, putusan pembebasan dari tindak pidana (vrijspraak), dalam hal menurut hasil pemeriksaan di persidangan, kesalahan terdakwa tidak terbukti secara sah dan meyakinkan atau berupa putusan lepas dan segala tuntutan hukum (onslaag van alle rechtsvervolging), perbuatan terdakwa sebagaimana yang didakwakan terbukti, akan tetapi perbuatan tersebut bukan merupakan suatu tindak pidana.

Proses atau tahapan penjatuhan putusan oleh hakim, dalam perkara pidana, menurut Moelyatno, dilakukan dalam beberapa tahapan, yaitu sebagai berikut. ${ }^{16}$

a. Tahap menganalisis perbuatan pidana

Menurut Moeljatno, unsur atau elemen perbuatan pidana adalah :

a. Kelakuan dan akibat.

b. Hal ikhwal atau keadaan yang menyertai perbuatan.

c. Keadaan tambahan yang memberatkan pidana.

d. Unsur melawan hukum yang objektif.

e. Unsur melawan hukum yang subjektif. ${ }^{17}$

b. Tahap menganalisis tanggung jawab pidana

Unsur-unsur pertanggungjawaban pidana untuk membuktikan adanya kesalahan pidana yang dilakukan oleh terdakwa harus dipenuhi hal-hal:

a. Melakukan perbuatan pidana (sifat melawan hukum).

b. Di atas umur tertentu dan mampu bertanggung jawab.

c. Mempunyai suatu bentuk kesalahan yang berupa kesengajaan atau kealpaan.

d. Tidak adanya alasan pemaaf. ${ }^{18}$

c. Tahap penentuan pemidanaan

16 Yusti Probowati Rahayu, Dibalik Putusan Hakim, Kajian Psikologi Hukum Dalam Perkara Pidana (Sidoharjo: Citramedia, 2005).

${ }_{17}$ Moeljatno, Asas-Asas Hukum Pidana (Jakarta: Rineka Cipta, 2002).

18 Moeljatno. 
Pada tahapan ini jikalau hakim berkeyakinan bahwa pelaku telah melakukan perbuatan yang melawan hukum, sehingga pelaku dinyatakan bersalah atas perbuatannya, dan kemudian perbuatannya itu dapat dipertanggungjawabkan oleh si pelaku, maka hakim akan menjatuhkan pidana terhadap pelaku tersebut, dengan melihat pasal-pasal undangundang yang dilanggar oleh si pelaku.

Pada awalnya semua pengadilan negeri berwenang mengadili semua perkara pidana, namun setelah diberlakukan Undang-Undang nomor 46 Tahun 2009 Tentang Pengadilan Tindak Pidana Korupsi, kewenangan mengadili perkara korupsi diatur khusus sebagaimana pasal 2 UU No 46 Tahun 2009 yaitu : Pengadilan Tindak Pidana Korupsi merupakan pengadilan khusus yang berada di peradilan umum. Kemudian dipertegas dalam pasal 5 UU No 46 tahun 2009 yaitu " Pengadilan Tindak Pidana Korupsi merupakan satu-satunya pengadilan yang berwenang memeriksa, mengadili dan memutus perkara tindak pidana korupsi."

Hakim diberi wewenang oleh undang-undang untuk menerima, memeriksa, dan memutus suatu perkara pidana. Dengan kewenangan tersebut, maka hakim harus berbuat adil dalam menangani suatu perkara. ${ }^{19}$ Hakim dalam mengani suatu perkara dalam membuat suatu pustusan harus mempertimbangan fakta dan peristiwa yang sebenarnya terjadi yang terungkap dalam persidangan. Dengan berdasarkan aspek fakta dan peristiwa tersebut hakim dalam melakukan penemuan hukum yang tepat sehingaa keputusan hakim dapat dipertanggungjawabkan. ${ }^{20}$

Kewenangan hakim dalam menangani tindak pidana korupsi pada awal pembentukan Pengadilan Tipikor, diatur dalam Pasal 56 ayat (1) Undangundang No. 30 Tahun 2002 Tentang Komisi Pemberantasan Korupsi mengenai hakim yang memeriksa perkara korupsi di Pengadilan Tindak Pidana Korupsi terdiri atas hakim pengadilan negeri, sering disebut juga hakim karir dan hakim ad hoc sehingga salah satu karakterisitik dari Pengadilan Tindak Pidana Korupsi (Tipikor) yang membedakannya dengan pengadilan umum dalam memeriksa perkara korupsi adalah komposisi hakimnya. ${ }^{21}$

\section{B. Putusan Hakim Tentang Pidana Uang Pengganti Dalam Perkara Yang Tidak Didakwakan Pasal 18 UU Tipikor}

19 Yohana Puspitasari Wardoyo Sulardi, "Kepastian Hukum, Kemanfaatan, Dan Keadilan Terhadap Perkara Pidana Anak: Kajian Putusan Nomor 201/Pid.Sus/2014/PN.Blt.," Jurnal Yudisial 8, no. 3 (2015): 251-68, https://doi.org/http://dx.doi.org/10.29123/jy.v8i3.57.

20 Rusman, Oksep Adhayanto, Ayu Efritadewi, "Tinjauan Yuridis Terhadap Tindak Pidana Korupsiberdasarkan Putusan Nomor 3 / Pid.Sus-Tpk / 2018 / PN Tpg ( Studi Pidana Uang Pengganti )," Student Online Journal 1, no. 2 (2020): 888-98.

${ }^{21}$ Rusman, Oksep Adhayanto, Ayu Efritadewi. 
Akibat yang ditimbulkan dari perbuatan korupsi sangatlah berbahaya untuk stabilitas dan keamanan negara. Korupsi bisa mempengaruhi dalam segala bidang dan sektor kehidupan masyarakat secara luas. Tindak pidana korupsi yang bisa membudidaya di negeri ini dapat menjadikan timbulnya krisis ekonomi, rusaknya nilai-nilai demokrasi dan nilai moralitas bangsa. ${ }^{22}$

Salah satu unsur Tipikor di dalam Pasal 2 dan Pasal 3 UU 31 Tahun 1999 jo. UU 20 Tahun 2001 adalah adanya kerugian keuangan negara. Unsur tersebut memberi konsekuensi bahwa pemberantasan Tipikor tidak hanya bertujuan untuk membuat jera para koruptor melalui penjatuhan pidana penjara yang berat, melainkan juga memulihkan keuangan negara akibat korupsi, sebagaimana ditegaskan dalam Konsiderans dan Penjelasan Umum UU 31 Tahun 1999. Oleh UU, instrumen untuk memulihkan keuangan negara tersebut dimasukkan dalam pidana tambahan berupa pembayaran uang pengganti. Mengutip Paragraf 8 Penjelasan UU 31 Tahun 1999 “....UU ini memuat juga pidana penjara bagi pelaku tindak pidana korupsi yang tidak dapat membayar pidana tambahan berupa uang pengganti kerugian negara." Rumusan tersebut menyuratkan bahwa uang pengganti bertujuan untuk mengganti kerugian negara. ${ }^{23}$

Keberadaan Pengadilan Tipikor saat ini belum di semua pengadilan negeri tetapi baru beberapa pengadilan negeri yang ditetapkan sebagai Pengadilan Tindak Pidana Korupsi. Pengadilan negeri yang berwenang mengadili perkara korupsi ditetapkan dengan Surat Keputusan Ketua Mahkamah Agung Republik Indonesia Nomor: 153/KMA/SK/X/2011, tanggal 11 Oktober 2011 tentang Pengoperasian Pengadilan Tindak Pidana Korupsi di beberapa daerah Indonesia salah satunya adalah Pengadilan Tipikor pada Pengadilan Negeri Banda Aceh, yang meliputi wilayah hukum seluruh wilayah Propinsi Aceh.

Berdasarkan data yang termuat di dalam Sistem Informasi Penelusuran Perkara pada Pengadilan Negeri/Tipikor Banda Aceh ditemukan 2 Perkara Korupsi yang duduk perkaranya sama yaitu dakwaan penuntut umum tidak mencantumkan ketentuan pasal 18 UU Tipikor namun diputus berbeda oleh hakim tentang pidana uang pengganti.

Salah satu permasalahan yang diangkat dalam penelitian ini terkait dengan penelusuran perkara pada Pengadilan Negeri/Tipikor Banda Aceh

22 Rika Ekayanti, "Perlindungan Hukum Terhadap Justice Collaborator Terkait Penanganan Tindak Pidana Korupsi Di Indonesia”, 4 (1), 2015, Hlm. 138," Jurnal Magister Hukum Udanaya 4, no. 1 (2015): 138-49.

${ }^{23}$ Ridwan, Hambali Thalib, and Hamza Baharuddin, "Journal of Lex Generalis (JLS)," Journal of Lex Theory 1, no. 2 (2020): 116-28, https://doi.org/https://doi.org/10.52103/jlg.v2i1.285. 
ditemukan perkara korupsi yang duduk perkaranya sama yaitu dakwaan penuntut umum tidak mencantumkan ketentuan Pasal 18 UU Tipikor namun diputus berbeda oleh hakim tentang pidana uang pengganti, yaitu Putusan Pengadilan Tindak Pidana Korupsi pada Pengadilan Negeri Banda Aceh Nomor 11/Pid.Sus-TPK/2019/PN. Bna, atas nama Terdakwa M. Mirza Ilvandi Alias Pandi Bin Ilyas, menjatuhkan pidana uang pengganti kepada Terdakwa.

1. Dakwaan berbentuk subsidairitas, Primair: Pasal 2 ayat (1) UU Tipikor, Jo. Pasal 55 Ayat (1) Ke-1 KUH Pidana, Subsidair : Pasal 3 UU Tipikor Jo. Pasal 55 Ayat (1) Ke-1 KUH Pidana.

2. Tuntutan Penuntut Umum:

a. Menyatakan terdakwa M. Mirza Ilvandi alias Pandi bin Ilyas terbukti secara sah dan meyakinkan menurut hukum bersalah melakukan tindak pidana "Setiap Orang Yang dengan Tujuan menguntungkan diri sendiri atau orang lain atau suatu korporasi,menyalahgunakan kewenangan, kesempatan atau sarana yang ada padanya karena jabatan atau kedudukan yang dapat merugikan keuangan negara atau perekonomian negara dan mereka yang melakukan, yang menyuruh melakukan, dan yang turut serta melakukan perbuatan", sebagaimana diatur dan diancam pidana dalam Pasal 3 Undang-Undang Nomor 31 Tahun 1999 tentang Pemberantasan Tindak Pidana Korupsi sebagaimana telah diubah dengan Undang-Undang Nomor20 Tahun 2001 tentang Perubahan Undang-Undang Nomor 31 Tahun 1999 tentang Pemberantasan Tindak Pidana Korupsi Jo. Pasal 55 ayat 1 ke-1 KUHP, dalam dakwaan Subsidair kami;

b. Menjatuhkan Pidana penjara terhadap Terdakwa M. Mirza Ilvandi alias Pandi bin Ilyas dengan pidana penjara selama 1 (satu) tahun dan 6 (enam) bulan dan denda sebesar Rp. 50.000.000,00 (lima puluh juta rupiah) subsidair 3 (tiga) bulan, dikurangkan dengan lamanya terdakwa berada didalam tahanan sementara dan dengan perintah agar terdakwa tetap berada didalam tahanan;

3. Membebani Terdakwa untuk membayar uang pengganti sebesar Rp. 344.404.482,00 (tiga ratus empat puluh empat juta empat ratus empat ribu empat ratus delapan puluh dua rupiah). Dalam perkara ini terdakwa M. Mirza Ilvandi Alias Pandi Bin Ilyas pada tahap Penuntutan telah menyerahkan/menitipkan uang tunai sebesar Rp190.000.000,00 (seratus sembilan puluh juta rupiah) untuk pembayaran uang pengganti sehingga sisa uang pengganti yang harus dibayarkan oleh terdakwa M. Mirza Ilvandi Alias Pandi Bin Ilyas sebesar Rp154.404.482,00 (seratus lima puluh empat juta empat ratus empat ribu empat ratus delapan puluh dua rupiah), apabila terdakwa tidak membayar sisa uang pengganti tersebut paling lama dalam waktu 1 (satu) bulan sesudah putusan Pengadilan memperoleh kekuatan hukum tetap, maka harta bendanya dapat disita oleh Jaksa 
dan dilelang untuk menutupi sisa uang pengganti tersebut, dalam hal terdakwa tidak mempunyai harta benda yang mencukupi untuk membayar uang pengganti maka diganti dengan pidana penjara selama 6 (enam) bulan.

Putusan Hakim :

1. Menyatakan Terdakwa Rifan Mailizar Bin H. Zamzami Abdul Gani tersebut diatas, tidak terbukti secara sah dan meyakinkan bersalah melakukan "Tindak Pidana" sebagaimana dalam dakwaan Primer;

2. Membebaskan Terdakwa oleh karena itu dari dakwaan Primer tersebut;

3. Menyatakan Terdakwa Rifan Mailizar Bin H. Zamzami Abdul Gani tersebut diatas, terbukti secara sah dan meyakinkan bersalah melakukan "Tindak Pidana Korupsi Secara Bersama-sama" sebagaimana dalam dakwaan Subsider;

4. Menjatuhkan pidana kepada Terdakwa oleh karena itu dengan pidana penjara selama 2 (dua) tahun denda sejumlah Rp50.000.000,00 (lima puluh juta rupiah) dengan ketentuan apabila denda tersebut tidak dibayar diganti dengan pidana kurungan selama 2 (dua) bulan;

5. Menghukum Terdakwa untuk membayar uang pengganti sejumlah Rp338.404.482,00 (tiga ratus tiga puluh delapan juta empat ratus empat ribu empat ratus delapan puluh dua rupiah).

Sekilas putusan ini telah mengabaikan asas kepastian hukum karena hakim telah menjatuhkan putusan di luar yang didakwakan oleh penuntut umum. Di mana pada perkara pidana dasar hakim menjatuhkan putusan berdasarkan kepada surat dakwaan dan segala sesuatu yang terbukti di saat pemeriksaan di persidangan.

Meskipun penuntut umum tidak mempertimbangkan dalam surat tuntutannya mengenai pidana tambahan, namun Majelis Hakim mempertimbangkan mengenai Pasal 18 Undang-undang Nomor 31 Tahun 1999 sebagaimana telah diubah dan ditambah dengan Undang undang Nomor 20 Tahun 2001 tentang Pemberantasan Tidak Pidana Korupsi yang mengatur tentang hukuman tambahan berupa pembayaran uang pengganti. Pada Pasal 18 Undang-undang Nomor 20 Tahun 2001 tentang Pemberantasan Tidak Pidana. Korupsi disebut secara jelas bahwa pembayaran uang pengganti sebesarbesarnya adalah sama dengan harta benda yang diperoleh dari tindak pidana korupsi tersebut, maka untuk menentukan jumlah besarnya uang pengganti harus diperhitungkan terlebih dahulu berapa uang negara yang telah diambil oleh terdakwa untuk kepentingan pribadinya, sehingga kerugian keuangan negara dapat dibebankan kepada terdakwa. ${ }^{24}$

\footnotetext{
${ }^{24}$ Ridwan, Thalib, and Baharuddin.
} 
Dasar pertimbangan hakim tetap menjatuhkan pidana uang pengganti kepada terdakwa meskipun surat dakwaan penuntut umum tidak dihubungkan (junto/jo) Pasal 18 UU Tipikor, sebagaimana diuraikan dalam pertimbangan hukum putusan pada halaman 103, yaitu sebagai berikut :

"Menimbang, bahwa walaupun penuntut umum di dalam surat dakwaannya tidak menjuctokan/menghubungkan Pasal 18 Undang-undang Nomor 31 tahun 1999 jo Undang-undang Nomor 20 tahun 2001 tentang Pemberantasan Tindak Pidana Korupsi, namun dalam perkara ini terdapat kerugian keuangan berdasarkan hasil audit dari BPKP dan juga berdasarkan fakta hukum yang terungkap dipersidangan Terdakwa M. Mirza Ilvandi alias Pandi Bin Ilyas telah menerima atau memperoleh uang dari kerugian keuangan negara tersebut dan terdakwa juga telah mengembalikan sebahagian dari kerugian keuangan negara yang diperolehnya tersebut, maka kepada terdakwa harus pula dibebankan untuk membayar uang pengganti;"

Dari pertimbangan hukum di atas terlihat hakim ragu-ragu menjatuhkan putusan pidana uang pengganti dalam perkara korupsi yang tidak didakwakan Pasal 18 UU Tipikor, tetapi karena terdakwa telah mengembalikan sebagian dari kerugian keuangan negara, maka hakim menghukum terdakwa untuk membayar uang pengganti, terlihat di sini faktor utama penjatuhan pidana uang pengganti bukan karena kepastian aturan UU Tipikor yang mewajibkan setiap orang yang merugikan keuangan negara dan menikmati uang korupsi harus dijatukan hukuman tambahan membayar uang pengganti.

Efektivitas pidana denda tidak memberikan efek jera bagi pelaku tindak pidana korupsi, karena pidana denda yang dijatuhkan kepada pelaku tindak pidana korupsi dapat diganti dengan pidana kurungan dan lamanya masa kurungan tidak sesuai dengan jumlah kerugian keuangan negara akibat perbuatan pelaku tindak pidana korupsi tersebut. Pidana ganti kerugian (denda) tidak memberikan efek jera bagi pelaku tindak pidana korupsi, karena pidana denda yang dijatuhkan kepada pelaku tindak pidana korupsi masih terlalu rendah jumlahnya. ${ }^{25}$

Dalam kasus ini hakim menjatuhkan putusan pidana uang pengganti kepada terdakwa meskipun pada Pasal 18 UU Tipikor dilatar belakangi karena terdakwa telah mengembalikan sebagian kerugian keuangan negara yang diperolehnya dari perbuatan korupsinya. Sistem peradilan pidana harus

25 Diding Rahmat, "Korupsi Di Indonesia Formulation of Fine Criminal Policies and Replacement Money in Criminal Enforcement," Jurnal IUS Kajian Hukum Dan Keadilan 8, no. 1 (2020): 78-88, https://doi.org/http://dx.doi.org/10.29303/ius.v8i1.686. 
menghindari mengandalkan pengakuan tersangka/terdakwa dalam pembuktian supaya tidak terjebak pada praktik pelanggaran HAM sebagaimana pengalaman berlakunya HIR. ${ }^{26}$

Hakim dilarang menjatuhkan putusan dengan kondisi ragu-ragu yang dikenal dengan asas "In Dubio Pro Reo" jika hakim ragu-ragu dengan sesuatu hal harusnya yang dilakukan hakim adalah memutuskan hal-hal yang menguntungkan untuk terdakwa. Dalam setiap menjatuhkan putusan hakim harus haqqul yaqin dengan putusan yang dijatuhkannya sebagaimana ketentuan Pasal 183 KUHAP yaitu "hakim tidak boleh menjatuhkan putusan kepada seorang terdakwa kecuali apabila dengan sekurang-kurangnya dua alat bukti yang sah ia memperoleh keyakinan bahwa suatu tindak pidana benarbenar terjadi dan bahwa terdakwalah yang bersalah melakukannya".

Pada putusan Pengadilan Tipikor Banda Aceh Nomor 11/Pid.SusTPK/2019/PN. Bna ini belum diperoleh argumen hukum yang kuat tentang boleh tidaknya hakim menjatuhkan putusan pidana uang pengganti dalam perkara korupsi yang tidak didakwakan Pasal 18 UU Tipikor. Namun demikian keberanian hakim ini mengambil putusan penjatuhan pidana uang pengganti kepada terdakwa sudah sewajarnya untuk diapresiasi. Perkara ini pun tidak dilakukan upaya hukum banding baik oleh penuntut umum dan terdakwa sehingga tidak dapat diuji oleh badan peradilan yang lebih tinggi.

Sedangkan dalam perkara Nomor 12/Pid.Sus-TPK/2018/PN. Bna, atas nama Terdakwa Rifan Mailizar Bin H. Zamzami Abdul Gani, hakim tidak menjatuhkan pidana uang pengganti kepada terdakwa, dengan amar putusan sebagi berikut :

1. Menyatakan Terdakwa Rifan Mailizar Bin H. Zamzami Abdul Gani tersebut diatas, tidak terbukti secara sah dan meyakinkan bersalah melakukan "Tindak Pidana" sebagaimana dalam dakwaan Primer;

2. Membebaskan Terdakwa oleh karena itu dari dakwaan Primer tersebut;

3. Menyatakan Terdakwa Rifan Mailizar Bin H. Zamzami Abdul Gani tersebut diatas, terbukti secara sah dan meyakinkan bersalah melakukan "Tindak Pidana Korupsi Secara Bersama-sama" sebagaimana dalam dakwaan Subsider;

4. Menjatuhkan pidana kepada Terdakwa oleh karena itu dengan pidana penjara selama 2 (dua) tahun denda sejumlah Rp50.000.000,00 (lima puluh juta rupiah) dengan ketentuan apabila denda tersebut tidak dibayar diganti dengan pidana kurungan selama 2 (dua) bulan;

Putusan Pengadilan Tindak Korupsi Pada Pengadilan Negeri Banda Aceh Nomor 12/Pid.Sus-TPK/2018/PN. Bna menolak menjatuhkan putusan pidana

${ }^{26}$ Moeljatno, Asas-Asas Hukum Pidana. 
uang pengganti dengan pertimbangan hukum putusan yang dirumuskan pada halaman 215 yaitu :

"Menimbang, bahwa dalam surat dakwaan Penuntut Umum yaitu dakwaan primer dan dakaan subsider tidak dihubungkan dengan ketentuan Pasal 18 Undang-undang Nomor 31 tahun 1999 jo Undangundang Nomor 20 tahun 2001 tentang Pemberantasan Tindak Pidana Korupsi, yaitu pasal yang mengatur tentang penjatuhan pidana tambahan bagi Terdakwa Rifan Milizar Bin H. Zamzami Abdul Gani yang terbukti melakukan tindak pidana korupsi dan ada memperoleh harta kekayaan dari tindak pidana yang dilakukannya tersebut, dan berdasarkan Pasal 182 ayat (4) KUHAP maka majelis tidak mempertimbangkannya, maka terhadap uang pengganti tersebut tidak dapat dibebankan kepada terdakwa".

Dari pertimbangan hukum di atas terlihat hakim perkara ini lebih menonjolkan asas kepastian hukum namun kalau dikaji secara hukum acara pidana yang berlaku putusan hakim tersebut yang mempermasalahkan bentuk atau formalitas surat dakwaan penuntut umum menjadi kewenangan materi eksepsi bagi terdakwa atau penasihat hukumnya sebagaimana kentuan Pasal 156 KUHAP namun instrumen hukum tersebut tidak digunakan oleh terdakwa atau penasihat hukum nya. Karena tidak ada keberatan tentang formalitas dakwaan tentunya perkaranya dilanjutkan pada pemeriksaan pokok perkara yang tentunya diakhiri dengan putusan hakim bersalah atau tidaknya terdakwa.

Dalam putusan ini juga tampak jelas hakim ragu-ragu mengadili perkara korupsi tidak didakwakan Pasal 18 UU Tipikor, dalam menjatuhkan ataupun membebaskan terdakwa dari pidana pembayaran uang pengganti kepada terdakwa Milizar Bin H. Zamzami Abdul Gani yang telah terbukti berdasarkan hasil pemeriksaan dipersidangan memperoleh harta benda dari perbuatan korupsinya" sehingga terlihat argumen hukumnya sangat dangkal dan belum memberikan dasar hukum bagi hakim lain untuk mengikuti putusan tersebut jika menghadapi kasus yang sama ataupun serupa.

Problema di atas terjadi karena UU Tipikor tidak memberikan penjelasan rinci tentang proses penerapan Pasal 18 UU Tipikor, apakah harus dicantumkan secara tegas di dalam dakwaan penuntut umum. Demikian juga dengan KUHAP sebagai ketentuan hukum acara yang bersifat umum berlaku sebagai pedoman penangan semua perkara pidana di Indonesia kecuali ditentukan lain dalam undang-undang khusus.

Pasal 18 UU Tipikor secara tegas menyatakan bahwa pidana uang pengganti merupakan pidana tambahan yang diatur khusus dalam UU Tipikor selain yang diatur dalam pasal 10 KUHP, tetapi KUHP sendiri tidak pula mengatur secara jelas bagaimana cara penerapan pidana tambahan, tersebut. 
KUHP hanya memberikan penjelasan makna masing-masing pidana tambahan (pencabutan hak-hak tertentu, perampasan barang tertentu dan pengumuman hakim).

Kejaksaan Agung Republik Indonesia pernah menerbitkan himbauan kepada seluruh jaksa penuntut umum melalui surat nomor :B209/F/Ft.1/10/2009 tanggal 30 Januari 2009, perihal bentuk surat dakwaan melanggar Pasal 2 ayat (1) dan Pasal 3 UU Tipikor dalam surat dakwaan, sebagaimana tertuang pada angka 6 menyebutkan :

"meskipun Pasal 18 UU Tipikor bukan merupakan unsur delik, akan tetapi Pasal 18 Undang-Undang Nomor 31 Tahun 1999 tetap perlu dicantumkan dalam surat dakwaan untuk memberikan kepastian supaya terdakwa dijatuhi hukuman tambahan atas pelanggaran terhadap pasal 2 ayat (1) dan pasal 3 Undang-Undang Nomor 31 tahun 1999”.

Jika ditelaah surat nomor :B-209/F/Ft.1/10/2009 tanggal 30 Januari 2009 yang diterbitkan oleh Kejaksaan Agung dari segi bentuknya hanyalah berupa surat biasa yang tidak termasuk ke dalam hiraraki peraturan perundang-undangan karena bukan berbentuk Peraturan Jaksa Agung (lihat Pasal 8 Undang-Undang Nomor 12 tahun 2011 tentang Pembentukan Peraturan Perundang-undangan) sehingga tidak bersifat mengikat bagi para penuntut umum secara hukum. Dari sisi isi muatannya juga bukan suatu perintah tetapi berupa anjuran kepada para jaksa penuntut umum, Namun demikian surat tersebut tidak pula memberikan penjelasan akibat hukum apabila Pasal 18 Undang-Undang Nomor 31 Tahun 1999 tidak dicantumkan dalam surat dakwaan. Namun demikian tentunya surat ini lahir karena sudah sering terjadi praktek penuntutan perkara korupsi yang tidak mencantumkan Pasal 18 Undang-Undang Nomor 31 Tahun 1999 dalam surat dakwaan jaksa penuntut umum.

Melihat fenomena di atas jelaslah ada kekosongan hukum tentang penerapan Pasal 18 UU Tipikor dalam praktek penanganan perkara korupsi, sehingga terjadi ketidak pastian hukum. Masyarakat tentunya menjadi bingung dengan kondisi hukum yang demikian. Dari penelaahan kasus di atas telah ditemukan masih ada kelemahan dalam penerapan hukum pidana uang pengganti Indonesia.

Sering sekali seorang hakim dalam mengadili suatu perkara terbentur dalam menentukan putusan karena tidak adanya hukum atau hukumnya tidak jelas dan lengkap, hal ini sudah diantisipasi oleh Undang-Undang Nomor 48 tahun 2009 tentang Kekuasaan Kehakiman yang diatur dalam Pasal 5 ayat (1) yang menyebutkan "hakim dan hakim konstitusi wajib menggali, mengikuti 
dan memahami nilai-nilai hukkum dan rasa keadilan masyarakat yang hidup ditengah masyarakat." oleh karenanya hakim juga dianggap tahu semua hukum (ius curia novit). Dalam kondisi ini maka hakim harus menggunakan kewenanganannya sebagai pejabat yang diamanatkan untuk melakukan penemuan hukum.

Fakta-fakta atau kejadian di atas merupakan beberapa permasalahan yang sering dihadapi oleh hakim dalam mengadili perkara korupsi yang dakwaannya penuntut umum tidak menjerat terdakwa dengan Pasal 18 UU Tipikor. Biasanya jika penuntut umum tidak menjerat terdakwa dengan Pasal 18 UU Tipikor maka penuntut umum di dalam berita acara penyidikan atau dalam surat dakwaannya tidak akan mendalami unsur aliran uang yang diterima oleh terdakwa hanya fokus kepada unsur perbuatan pidana yang dilakukan terdakwa serta tidak dilakukan lagi penyitaan terhadap aset terdakwa.

\section{PENUTUP}

Pasal 18 UU Tipikor adalah merupakan pidana tambahan yang menjadi sanksi khusus dalam perkara tindak pidana korupsi guna mengambil kembali uang negara dari para koruptor. Meskipun UU Tipikor tidak memberikan aturan tentang cara penerapan Pasal 18 karena pidana uang pengganti bukan sebagai rumusan unsur perbuatan pidana (delict) tetapi merupakan ketentuan materiil berupa sanksi tambahan khusus selain yang diatur dalam Pasal 10 KUHP tidak didakwakannya Pasal 18 UU Tipikor tidaklah menghilangkan kewenangan hakim untuk menjatuhkan pidana uang pengganti kepada terdakwa. Pidana pengganti sebagai pidana tambahan yang sifatnya fakultatif tetapi bagi terdakwa yang telah terbukti menikmati aliran uang korupsi mestinya penjatuhan pidana uang pengganti bersifat imperatif dilakukan oleh hakim. Selain masalah penjatuhan pidana uang pengganti juga terjadi disparitas dalam penjatuhan pidana penjara pengganti apabila uang pengganti tidak dibayarkan oleh terdakwa, sering terjadi penjatuhan pidana penjara pengganti tidak sepadan dengan nilai uang pengganti yang harus dibayarkan. Keputusan hakim untuk tidak menjatuhkan pidana uang penganti lebih menonjolkan asas kepastian hukum atas tidak adanya tuntutan dari jaksa penuntut umum akan adanya pidana uang pengganti.

\section{DAFTAR PUSTAKA}

Abdul Fatah, Nyoman Serikat Putra Jaya, Henny Juliani. "Kajian Yuridis Penerapan Unsur Merugikan Keuangan Negara Dalam Penegakan Hukum Tindak Pidana Korupsi." Diponegoro Law Review 6, no. 31 (2017): 1-15.

Ade Mahmud. "Dinamika Pembayaran Uang Pengganti Dalam Tindak Pidana Korupsi.” Jurnal Hukum Mimbar Justitia 3, no. 2 (2017): 137-56.

Ali, Dahlan. "Eksekusi Uang Pengganti Terhadap Terpidana Dalam Tindak Pidana Korupsi Oleh Kejaksaan Tinggi Aceh.” Kanun: Jurnal Ilmu
Hukum
18 ,
no.
2
(2016):
319-36. 
https://doi.org/10.24815/kanun.v18i2.5927.

Ali, Mahrus. Asas, Teori \& Praktek Hukum Pidana Korupsi. Yogyakarta: UII Press, 2013.

Ekayanti, Rika. "Perlindungan Hukum Terhadap Justice Collaborator Terkait Penanganan Tindak Pidana Korupsi Di Indonesia”, 4 (1), 2015, Hlm. 138." Jurnal Magister Hukum Udanaya 4, no. 1 (2015): 138-49.

Laowo, Yonathan Sebastian. "Analisis Yuridis Putusan Bebas Dalam Tindak Pidana Korupsi." Education And Development 4, no. 1 (2018): 90-91. http://journal.ipts.ac.id/index.php/ED/article/view/281/158.

Machmud, Bahrudin, Muhammad Junaidi, and Amri Panahatan Sihotang. "Reposisi Kedudukan Justice Collaborator Dalam Upaya Pemberantasan Tindak Pidana Korupsi." USM Law Review 4, no. 1 (2021): 362-77. https://doi.org/http://dx.doi.org/10.26623/julr.v4i1.3368.

Mahmud, Ade. "Problematika Asset Recovery Dalam Pengembalian Kerugian Negara Akibat Tindak Pidana Korupsi.” Jurnal Yudisial 11, no. 3 (2018): 347. https://doi.org/10.29123/jy.v11i3.262.

Mahmud Mulyadi, M. Hamda, Hasim Purba. "Tinjauan Yuridis Terhadap Putusan Hakim Dalam Penjatuhan Hukuman Badan Sebagai Pengganti Dalam Pembayaran Uang Pengganti Dalam Perkara Tindak Pidana Korupsi." USU Law Journal 4, no. 2 (2016): 42-55.

Mamudji, Soerjono Soekanto dan Sri. Penelitian Hukum Normatif (Suatu Tinjauan Singkat). Jakarta: Raja Grafindo Persada, 2010.

Moeljatno. Asas-Asas Hukum Pidana. Jakarta: Rineka Cipta, 2002.

Noviyanti, Rahma, Elwi Danil, and Yoserwan Yoserwan. "Penerapan Perma Nomor 5 Tahun 2014 Tentang Pidana Tambahan Uang Pengganti Dalam Tindak Pidana Korupsi." Jurnal Wawasan Yuridika 3, no. 1 (2019): 1. https://doi.org/10.25072/jwy.v3i1.236.

Puteri, Rizqi Purnama, Muhammad Junaidi, and Zaenal Arifin. "Reorientasi Sanksi Pidana Dalam Pertanggungjawaban Korporasi Di Indonesia." Jurnal Usm Law Review 3, no. 1 (2020): 98-111. https://doi.org/10.26623/julr.v3i1.2283.

Putri, Nastiti Rahajeng. "Penjatuhan Pidana Uang Pengganti Sebagai Pidana Tambahan Dalam Perkara Tindak Pidana Korupsi.” Jurnal Ilmiah Galuh Justisi 6, no. 1 (2018): 42. https://doi.org/10.25157/jigj.v6i1.1239.

Rahmat, Diding. "Korupsi Di Indonesia Formulation of Fine Criminal Policies and Replacement Money in Criminal Enforcement." Jurnal IUS Kajian Hukum Dan Keadilan 8, no. 1 (2020): 78-88. https://doi.org/http://dx.doi.org/10.29303/ius.v8i1.686.

Ridwan, Hambali Thalib, and Hamza Baharuddin. "Journal of Lex Generalis (JLS)." Journal of Lex Theory 1, no. 2 (2020): 116-28. https://doi.org/https://doi.org/10.52103/jlg.v2i1.285.

Rusman, Oksep Adhayanto, Ayu Efritadewi. "Tinjauan Yuridis Terhadap Tindak Pidana Korupsiberdasarkan Putusan Nomor 3 / Pid.Sus-Tpk / 2018 / PN Tpg ( Studi Pidana Uang Pengganti )." Student Online Journal 1, no. 2 (2020): 888-98.

Sulardi, Yohana Puspitasari Wardoyo. "Kepastian Hukum, Kemanfaatan, Dan 
p-ISSN : 2541-2345, e-ISSN : 2580-8842

Keadilan Terhadap Perkara Pidana Anak: Kajian Putusan Nomor 201/Pid.Sus/2014/PN.Blt." Jurnal Yudisial 8, no. 3 (2015): 251-68. https://doi.org/http://dx.doi.org/10.29123/jy.v8i3.57.

Suyanto, Aryas Adi. "Komisi Pemberantasan Korupsi Sebagai Lembaga Korupsi Di Indonesia.” Jurnal USM Law Review 1, no. 1 (2018): 39-67. https://doi.org/http://dx.doi.org/10.26623/julr.v1i1.2231.

Yusti Probowati Rahayu. Dibalik Putusan Hakim, Kajian Psikologi Hukum Dalam Perkara Pidana. Sidoharjo: Citramedia, 2005. 